\title{
Application of Reduced Stiffiness of Complex Laminate in Finite Elements for Chair Analysis
}

\section{Primjena reducirane krutosti kompleksnog laminata u konačnim elementima za analizu stolaca}

\author{
Preliminary paper • Prethodno priopćenje \\ Received-prispjelo: 12. 12. 2014. \\ Accepted-prihvaćeno: 6. 11. 2015. \\ UDK: $630 * 812.712 ; 630 * 832.286 ; 630 * 836$ \\ doi:10.5552/drind.2015.1445
}

\begin{abstract}
This paper presents a numerical procedure for the analysis of complex laminate structures. The procedure is based on the application of reduced stiffness of complex laminate. Introduction of reduced stiffness of composite facilitates both linear and nonlinear numerical integration, i.e. the tangential stiffness matrix is translated in the classical plate theory problem. The formulated numerical procedure was implemented in the program system KOMIPS. Special subroutine REDKRUT that calculates reduced stiffness of the laminate was written, and its application in numerical verification of experiments conducted on chairs was presented in (Nestorovic, 2010). At the end of this work, for 3D stress and strain analysis of veneer composites, recommendations were given for experimental determination of all nine independent material constants $E_{x}, E_{y}, E_{z}, v_{x y}, v_{x z}, G_{x y}, G_{x z}, G_{y z}$, five of which were determined in the previous paper of the author (Nestorović, 2010).
\end{abstract}

Key words: reduced stiffness, finite elements, composite, material constants, shell, chair

\begin{abstract}
SAŽETAK・Rad prikazuje numeričku proceduru za analizu struktura izrađenih od kompleksnih laminata. Postupak se temelji na primjeni reducirane krutosti komplesnog laminata. Uvođenjem reducirane krutosti kompozita numerička se integracija, kako linearne, tako i nelinearne, odnosno tangencijalne matrice krutosti, prevodi u problem klasične teorije ploča. Formulirana numerička procedura implementirana je u sklopu programskog paketa KOMIPS. Napisana je posebna subrutina REDKRUT, kojom se proračunavaju reducirane krutosti laminata, a njegova primjena u provjeri numeričkih eksperimenata provedenih na stolcima prikazana je u radu (Nestorovic, 2010.). Za 3-D analizu naprezanja i deformacija furnirskih kompozita na kraju ovog rada dane su preporuke za eksperimentalno određivanje svih devet neovisnih materijalnih konstanti: $E_{x}, E_{y}, E_{z}, v_{x y}, v_{x z}, G_{x y}, G_{x z}, G_{y z}$ od kojih je pet određeno u prethodnom autoričinu radu (Nestorović, 2010.).
\end{abstract}

Ključne riječi: reducirana krutost, konačni elementi, kompozit, materijalne konstante, ljuska, stolac

\footnotetext{
${ }^{1}$ Author is assistant professor at University of Belgrade Faculty of Forestry, Belgrade, Serbia. ${ }^{2}$ Author is professor at Faculty of Forestry, University of Zagreb, Zagreb, Croatia. ${ }^{3}$ Authors are PhD candidates at University of Belgrade, Faculty of Architecture, Belgrade, Serbia.

Autorica je docentica Šumarskog fakulteta Sveučilišta u Beogradu, Beograd, Srbija. ${ }^{2}$ Autor je profesor Šumarskog fakulteta Sveučilišta u Zagrebu, Zagreb, Hrvatska. ${ }^{3}$ Autori su doktorandi Fakulteta arhitekture Sveučilišta u Beogradu, Beograd, Srbija.
} 


\section{INTRODUCTION}

\section{UVOD}

Theoretical basis of linear elastic anisotropic and orthotropic material is the concept that implies definition of stress-strain as well as reciprocal strainstress dependencies. From the general 3D state of stress, 2D case that represents conditions of plane state of stress was derived, and for these conditions classical thin plate and shell theory were applied, with the focus on wood composite structures. By introducing reduced stiffness of composites, both linear and nonlinear numerical integrations of respective tangential stiffness matrixes were translated into the problem of classical plate theory.

The aim of this paper was to specify a mathematical model for the calculation of complex laminate, and develop the procedure that applies reduced plate, which can reliably replace the use of complex laminate. We presented a formulation of composite finite plate element in the case of geometrical and material linear and nonlinear treatments by application of reduced stiffness of the composite, concluding with the recommendations and guidelines for further researches. The paper represents an integral part of the research presented in (Nestorović, 2010), certain parts of which, referring to the results of FEM calculations and experimental measurements, were previously published in (Nestorovic et al., 2011, 2012, 2013; Nestorović and Grbac, 2011).

\subsection{Laminae as arbitrary layer of laminate} 1.1. Lamela kao proizvoljni sloj laminata

The structure of the laminate represents the compound of a number of laminae, whose principal material directions are oriented to enable the laminate structural capability to resist loads in different directions. Application of Classical Lamination Theory
(CLT) facilitates the explanation of laminate structure starting from its base building layer - laminae.

CLT in the conditions of bending is based on Kirchhoff-Lowe hypothesis of flat sections before and after deformation. Namely, the linear element orthogonal to the mid-plane of the laminate after deformation remains flat, unchanged in length and perpendicular to the deformed mid-surface of the laminate. This condition will be fulfilled only if all compatibility conditions of overlapping of displacements in all points of the laminae with the adjacent layers are satisfied. Hence, it can be concluded that laminae behaves as a layer with special properties. With this in mind, it is possible to determine the change of dilatation and stress through the thickness of the laminate.

The technical hypothesis of length changelessness and linear element orthogonallity on the midplane of the laminate before and after deformation (direction $\mathrm{ABCD}$ under deformation, Figure 1), means that dilatations in $z$ direction, as well as shear deformations in plans orthogonal to the mid-plane of the laminate, equal zero $\left(\varepsilon_{z}=\gamma_{x z}=\gamma_{y z}=0\right)$.

If displacement is denoted in the $\mathrm{x}$-direction of the point $\mathrm{B}$, which is not the mid-plane of the laminate, with, than the displacement of the arbitrary point $\mathrm{C}$, on equidistance from the middle plane in the same direction, is

$$
u_{c}=u_{o}+z_{c} \beta_{y}
$$

where is rotation of the cross section of laminate around y-axis

$$
\beta_{y}=-\frac{\partial w}{\partial x} \quad w=w_{0}=\text { const }
$$

Let and be displacements of the points on the middle plane in the directions of $x, y$, and $z$-axis. Based on the expressions (1) and (2), it can be concluded that displacement in any point through the thickness of the cross section of the laimate is

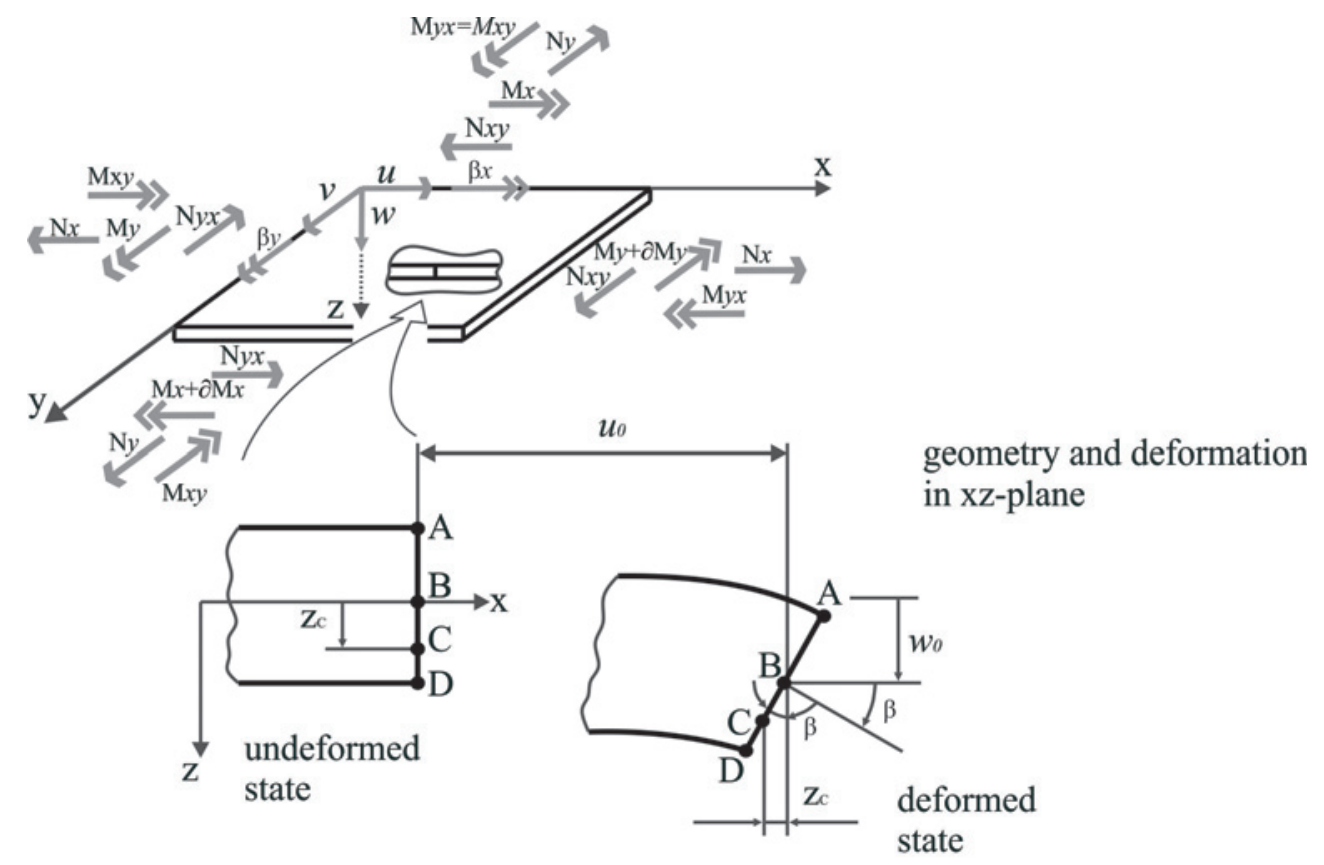

Figure 1 Laminate plate under bending

Slika 1. Laminatna ploča u uvjetima savijanja 
.... Nestorović, Grbac, Nestorović, Milošević: Application of Reduced Stiffness of Complex...

$$
u=u_{o}-z \frac{\partial w}{\partial x}
$$

Consequently, displacement in the y direction is

$$
v=v_{o}-z \frac{\partial w}{\partial y}=v_{0}-z \beta_{x}, \quad \beta_{x}=\frac{\partial w}{\partial y}
$$

where $\beta_{x}$ is rotation of the cross section of the laminate around $\mathrm{x}$-axis.

Having in mind geometrical relations that established dependence between strains and displacements

$$
\varepsilon_{x}=\frac{\partial u}{\partial x}, \varepsilon_{y}=\frac{\partial v}{\partial u}, \quad \gamma_{x y}=\frac{\partial u}{\partial y}+\frac{\partial v}{\partial x}
$$

Using matrix notation, the following equation can be expressed:

$$
\begin{aligned}
\varepsilon_{x 0}^{T} & =\left[\begin{array}{lll}
\varepsilon_{x 0} & \varepsilon_{y 0} & \gamma_{x y 0}
\end{array}\right]= \\
& =\left[\begin{array}{lll}
\frac{\partial u_{o}}{\partial x} & \frac{\partial v_{o}}{\partial y} & \frac{\partial u_{o}}{\partial y}+\frac{\partial v_{o}}{\partial x}
\end{array}\right]=\varepsilon_{x 0}+z \kappa
\end{aligned}
$$

whereis the mid-plane strain and $\kappa$ is the vector of second derivatives of the displacement, i.e. curvature

$$
\kappa^{T}=\left[\begin{array}{lll}
\kappa_{x} & \kappa_{y} & \kappa_{x y}
\end{array}\right]=-\left[\begin{array}{lll}
\frac{\partial^{2} w}{\partial x^{2}} & \frac{\partial^{2} w}{\partial y^{2}} & 2 \frac{\partial^{2} w}{\partial x \partial y}
\end{array}\right]
$$

The component $\kappa_{x y}$ is a twisting curvature, stating how the x-direction mid-plane slope changes with y (or equivalently, how the $y$-direction slope changes with $\mathrm{x}$ ).

Having in mind that the geometrical relation (5) belongs to the plate theory, Jones (1975) stressed that the more correct designation for the classical lamination theory (CLT) would be the classical theory of laminated plates.

Stress and strain relations in the case of orthotropic laminae, in which the calculated and main material directions do not coincide, in accordance with equation (5), will be expressed as follows

$$
\sigma_{k}=\bar{Q}_{k} \varepsilon_{k}
$$

where $\bar{Q}$ denotes transformed stiffness matrix in the state of stress.

$$
\sigma_{x}=\bar{Q}_{k}\left(\varepsilon_{x 0}+z \kappa\right)
$$

Assumed forms of dilatation and stress change across the thickness of the laminate are given as an example in Figure 2.

\subsection{Forces and moments in laminate sections 1.2. Sile i momenti u presjecima laminata}

Figure 3 shows laminate of the thickness $h$ composed of Nlaminae. Z-axis is directed downward from the laminate midd-plane.
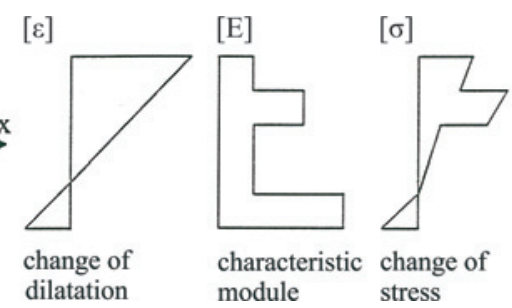

Figure 2 Change in dilatations and stresses across the laminate thickness

Slika 2. Promjena dilatacija i naprezanja po debljini laminata

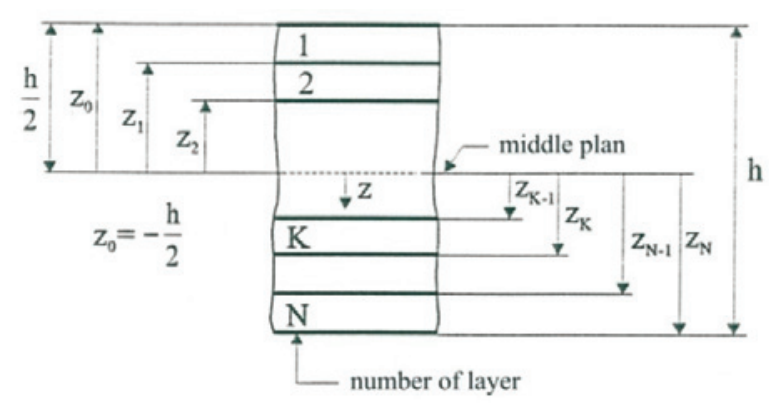

Figure 3 Coordinates and ordinal numbers of laminas in laminate

Slika 3. Koordinate i redni brojevi lamela u laminatu

Components of membrane forces and bending moments will be determined as

$$
\begin{gathered}
N=\int_{-h / 2}^{h / 2} \sigma d z=\sum_{k=1}^{N} \int_{z_{k-1}}^{z_{k}} \sigma d z \\
M=\int_{-h / 2}^{h / 2} z \sigma d z=\sum_{k=1}^{N} \int_{z_{k-1}}^{z_{k}} z \sigma d z
\end{gathered}
$$

while index " $k$ represents $k$-th laminae (layer) in the laminate.

Integrating the expression (10), it follows that

$$
\begin{aligned}
& N=\sum_{k=1}^{N} \bar{Q}_{k}\left(\int_{z_{k-1}}^{z_{k}} \varepsilon_{x 0} d z+\int_{z_{k-1}}^{z_{k}} z \kappa d z\right) \\
& M=\sum_{k=1}^{N} \bar{Q}_{k}\left(\int_{z_{k-1}}^{z_{k}} z \varepsilon_{x 0} d z+\int_{z_{k-1}}^{z_{k}} z^{2} \kappa d z\right)
\end{aligned}
$$

or,

$$
N=D_{m} \varepsilon_{x 0}+D_{m b} \kappa \quad M=D_{m b} \varepsilon_{x 0}+D_{b} \kappa
$$

where matrixes

$D_{m}=\sum_{k=1}^{N}\left(z_{k}-z_{k-1}\right) \bar{Q}_{k} \quad D_{m b}=\frac{1}{2} \sum_{k=1}^{N}\left(z_{k}^{2}-z_{k-1}^{2}\right) \bar{Q}_{k}$

$D_{b}=\frac{1}{3} \sum_{k=1}^{N}\left(z_{k}^{3}-z_{k-1}^{3}\right) \bar{Q}_{k}$

represent laminate stiffness on elongation, banding as well as coupled stiffness.

Based on the (12) and (13), it can be concluded that in general case of anisotropic laminate, membrane forces are not just a function of membrane deformation, but of the change of the curvature as well. On the other hand, it can be easily noted that bending moments and torsion moments in arbitrary laminate section do not only depend on a change of curvature of its mid-plan, but also on membrane deformations. The influence of the curvature change in the membrane section forces as well as the influence of membrane deformations on section bending forces is expressed by coupling stiffness of laminate $D_{m b}$.

\section{STIFNESSES OF THE LAMINATE AND LAMINAE}

\section{KRUTOSTI LAMINATA I LAMELE}

Coupling stiffness $D_{m b i j}$ is the consequence of both material characteristics of the laminate and geo- 
metrical arrangement of laminas in the laminate. Neglecting the influence of coupling stiffness, in the cases when they are present in the composite structures, could mischief the accuracy of stability calculations of these composite structures. Therefore, attention should be paid to the review of the following groups of composites, in specific laminates.

\subsection{Single-layer isotropic "laminate"}

2.1. Jednoslojni izotropni laminat

Though the notion laminate implies multilayer structure, Jones (1975) used this name with the intention to demonstrate that laminate stiffness, given by the relations (13), could be reduced to the level of isotropic plate stiffness.

On that basis, from the expression (13), it can be concluded that in the case of isotropic plate there is no coupling between banding and stretching, i.e. expressions for the forces and moments are

$$
\left[\begin{array}{c}
N \varepsilon \\
M
\end{array}\right]=\left[\begin{array}{ll}
D_{m} & \\
& D_{b}
\end{array}\right]\left[\begin{array}{c}
x 0 \\
\kappa
\end{array}\right]
$$

whereby stiffness matrixes $D_{m}$ and $D_{b}$ have the following values

$$
\begin{aligned}
D_{m} & =\left[\begin{array}{ccc}
D_{m} & v D_{m} & 0 \\
v D_{m} & D_{m} & 0 \\
0 & 0 & 1-v D_{m}
\end{array}\right] \\
D_{b} & =\left[\begin{array}{ccc}
D_{b} & v D_{b} & 0 \\
v D_{b} & D_{b} & 0 \\
0 & 0 & \frac{1-v}{2} D_{b}
\end{array}\right] \\
\text { where } \quad D_{m} & =\frac{E \cdot h}{1-v^{2}} \quad D_{b}=\frac{E \cdot h^{3}}{12 \cdot\left(1-v^{2}\right)}
\end{aligned}
$$

\subsection{Special orthotropic laminae}

\subsection{Posebna ortotropna lamela}

In the case of special orthotropic laminae of thickness $h$ and stiffness $Q_{\mathrm{ij}}$, given the equation (14), material stiffness matrixes have the following form

$$
\begin{aligned}
D_{m} & =\left[\begin{array}{ccc}
D_{m 11} & D_{m 12} & 0 \\
D_{m 21} & D_{m 22} & 0 \\
0 & 0 & D_{m 66}
\end{array}\right] \\
D_{b} & =\left[\begin{array}{ccc}
D_{b 11} & D_{b 12} & 0 \\
D_{b 21} & D_{b 22} & 0 \\
0 & 0 & D_{b 66}
\end{array}\right]
\end{aligned}
$$

with the components

$$
\begin{aligned}
D_{m 11} & =Q_{11} h \quad D_{m 12}=Q_{12} h \quad D_{m 22}=Q_{22} h \quad D_{m 66}=Q_{66} h \\
D_{b 11} & =Q_{11} \frac{h^{3}}{12} \quad D_{b 12}=Q_{12} \frac{h^{3}}{12} \quad D_{b 22}= \\
& =Q_{22} \frac{h^{3}}{12} \quad D_{b 66}=Q_{66} \frac{h^{3}}{12}
\end{aligned}
$$

where it can be seen that in the case of laminae, in which geometrical (calculated) main directions coincide with main directions of material characteristics, there is no coupling between bending and membrane stress.

\section{EQUILIBRIUM EQUATIONS OF LAMINATED PLATES}

\section{JEDNADŽBE RAVNOTEŽE LAMELIRANIH} PLOČA

In the study of laminated plate theory, inputs are based on the following constraints and assumptions: each laminae in the laminate is orthotropic, linear elastic, of constant thickness, so that laminate (plate) has also constant thickness, which is small compared to the other dimensions; further, there are no internal friction forces, Kirchhoff hypothesis of non-deformable normal on the mid-plan is applicable, displacements $\mathrm{u}, \mathrm{v}$, and $\mathrm{w}$ are small compared to the plate thickness and dilatations $e_{x}, e_{y}$ and $g_{x y}$ are infinitesimal values.

Differential equations of equilibrium of laminate plates under load perpendicular to the mid-plane of laminate $\mathrm{p}$, expressed via resultant forces $N_{x}, N_{y}$ and $N_{x y}$ and moments $M_{x}, M_{y}$ and $M_{x y}$, have the following form

$$
\begin{aligned}
& \frac{\partial N_{x}}{\partial x}+\frac{\partial N_{x y}}{\partial y}=0 \\
& \frac{\partial N_{x y}}{\partial x}+\frac{\partial N_{y}}{\partial y}=0 \\
& \frac{\partial^{2} M_{x}}{\partial x^{2}}+2 \frac{\partial^{2} M_{x y}}{\partial_{x} \partial_{y}}+\frac{\partial^{2} M y}{\partial y^{2}}=p
\end{aligned}
$$

Differential equations of equilibrium are very simplified when it comes to special orthotropic laminates. This leads to differential equations of equilibrium for special orthotropic laminate (plate)

$D_{m 11} u_{, x x}+D_{m 66} u_{, y y}+\left(D_{m 12}+D_{m 66}\right) v_{, x y}=0$,
$\left(D_{m 12}+D_{m 66}\right) u_{, x y}+D_{m 66} v_{, x x}+D_{m 22} v_{, y y}=0$,
$D_{b 11} w_{, x x x x}+2\left(D_{b 12}+2 D_{b 66}\right) w_{, x x y y}+D_{b 22} w_{, y y y y}=p(x, y)$.

\section{APPLICATION OF FEM FOR STRUCTURAL} ELEMENTS OF CHAIRS

\section{PRIMJENA METODE KONAČNIH ELEMENATA NA ELEMENTIMA KONSTRUKCIJE STOLACA}

Finite element of laminate will be obtainted by integration of finite elements per thickness of the laminate. This integration is not a mathematical problem, and in the finite element methodology, it is known as layered approach. It could be concluded that the laminate element represents a layered finite element. For this reason, in order to formulate the finite element of laminate, it is first necessary to formulate finite laminae element of unit thickness.

\subsection{Finite laminate element}

4.1. Konačni element laminata

The finite laminate element represents a composite of finite elements of laminaes. Since each laminae 


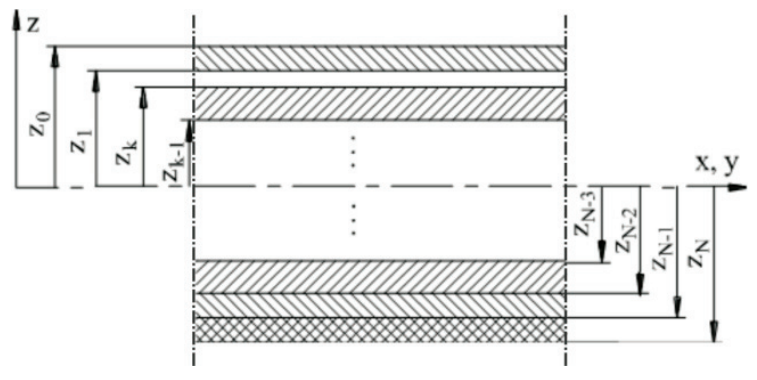

Figure 4. Finite laminae element - thickness cross section Slika 4. Konačni element laminata - presjek po debljini

in the laminate represents a layer of constant thickness, it follows that the formulation of the finite element of the laminae is subjected to so call layered approach of finite element. Compatibility conditions for displacements and deformations of layers are satisfied not only at nodal points, but in any point within laminae (layer) element. Integration of stiffness matrix per surface of the laminate remains the same as in the case of the single laminae, while thickness integration requires integration of each layer individually in relation to the local coordinate system of the laminate positioned in its middle plane (Figure 4).

Accordingly to this statement, it could be concluded that

$K_{L}=\int_{z}\left(\int_{A}\left[\begin{array}{cc}B_{m}^{T} & \\ & B_{b}^{T}\end{array}\right]\left[\begin{array}{ll}Q & \\ & z^{2} Q\end{array}\right]\left[\begin{array}{ll}B_{m} & \\ & B_{b}\end{array}\right] d A\right) d z$

Where $A$ denotes integration across the surface of the mid-plane of plate, and $z$ integration over its cross section.

Having in mind that surface integrals of laminate represent stiffness matrixes of laminae multiplied by specified multipliers, the final form of the above expression will be as follows:

$$
\begin{aligned}
& K_{L}=\sum_{k=1}^{N}\left[\begin{array}{cc}
z_{k}-z_{k-1} & \\
& \frac{z_{k}^{3}-z_{k-1}^{3}}{3}
\end{array}\right]\left[\begin{array}{ll}
\frac{1}{t_{k}} K_{m k} & \\
& \frac{12}{t_{k}^{3}} K_{b k}
\end{array}\right]= \\
& =\sum_{k=1}^{N}\left[\begin{array}{cc}
\frac{z_{k}-z_{k-1}}{t_{k}} K_{m k} & \\
& \frac{4\left(z_{k}^{3}-z_{k-1}^{3}\right)}{t_{k}^{3}} K_{b k}
\end{array}\right]
\end{aligned}
$$

where $K_{m k}$ and $K_{b k}$ are membrane and stiffness matrixses of banding of $k$-th laminae.

If the laminate has asymmetry property with respect to the z-axis (Figure 4), its stiffness matrix, like in the case of laminae, could be decomposed on the membrane and stiffness matrix of laminate bending. If the membrane stress is coupled with bending procedure of integration of laminate, stiffness matrix stays the same, with the difference that in the matrix of diagonal blocks, $\mathbf{Q}_{k}$ also appear out-of-diagonal blocks in accordance with the expressions (13) so that

$K_{L}=\int_{z}\left(\int_{A}\left[\begin{array}{cc}B_{m}^{T} & \\ & B_{b}^{T}\end{array}\right]\left[\begin{array}{cc}Q & z Q \\ z Q^{T} & z^{2} Q\end{array}\right]\left[\begin{array}{cc}B_{m} & \\ & \\ & B_{b}\end{array}\right] d A\right) d z$

\subsection{Reduced stiffness of laminate}

4.2. Reducirana krutost laminata

In the case when all layers of the laminate are of equal thickness, equal orientation and equal mechanical characteristics, laminate stiffness matrix (22) becomes

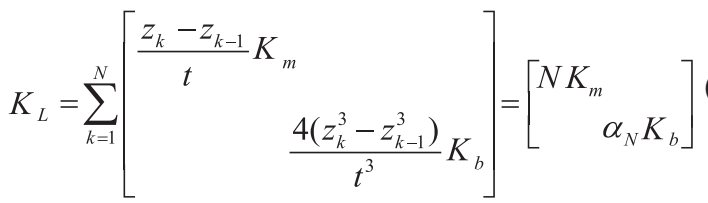

where

$$
\alpha_{N}=\frac{4}{t^{3}} \sum_{k=1}^{N}\left(z_{k}^{3}-z_{k-1}^{3}\right)
$$

In accordance with the expression (24), in this case the entire laminate could be viewed as a single layer, whereby multipliers $N$ and $\alpha_{N}$ are attached to the material stiffnesses, with the aim to encompass integration through the thickness of the laminate, i.e.

$$
D_{m}^{r}=N D_{m} \quad D_{b}^{r}=\alpha_{N} D_{b}
$$

Thus, reduced membrane $D_{m}^{r}$ and banding stiffness $D_{b}^{r}$ are defined. As a result, sub-matrixes of the laminate stiffness matrix were found by integration only per surface of element, i.e.

$$
K_{L m}=\int_{A} B_{m}^{T} D_{m}^{r} B_{m} d A \quad K_{L b}=\int_{A} B_{b}^{T} D_{b}^{r} B_{b} d A
$$

If laminas do not possess the same mechanical properties, laminate stiffness matrix could also be given by the specified expression, where reduced stiffnesses are defined in the following way, based on the expressions (22):

$D_{m}^{r}=\frac{1}{t} \sum_{k=1}^{N}\left(z_{k}-z_{k-1}\right) D_{m k} \quad D_{b}^{r}=\frac{4}{t^{3}} \sum_{k=1}^{N}\left(z_{k}^{3}-z_{k-1}^{3}\right) D_{b k}$

In the case when different thickness, different orientation and different mechanical properties of the laminas are assumed, expression (28) becomes

$$
D_{m}^{r}=\sum_{k=1}^{N}\left(z_{k}-z_{k-1}\right) \bar{Q}_{k} \quad D_{b}^{r}=\sum_{k=1}^{N} \frac{1}{3}\left(z_{k}^{3}-z_{k-1}^{3}\right) \bar{Q}_{k}
$$

where $\bar{Q}_{k}$ represents constitutive layer matrixes with respect to the computational Cartesian coordinates.

For the general case defined by the expression (23), stiffness matrix of the composite will be expressed as

where

$$
K_{L}=\left[\begin{array}{cc}
K_{L m} & K_{L m b} \\
K_{L b m} & K_{L b}
\end{array}\right]
$$

$$
K_{\text {Lbm }}=\int_{A} B_{m}^{T} D_{m b}^{r} B_{b} d A=K_{L m b}^{T}
$$

is coupling laminate stiffness matrix, while

$$
D_{m b}^{r}=\sum_{k=1}^{N} \frac{1}{2}\left(z_{k}^{2}-z_{k-1}^{2}\right) \bar{Q}_{k}
$$

represents reduced coupling laminate stiffness.

The stiffness matrix of the composite plate (29) includes the effects of coupling of membrane stress and bending of laminate. This kind of coupling occurs in anisotropic and in orthotropic composite plates only if laminas are not symmetrically arranged both per ge- 
ometry and material in relation to the mid-plane of the plate. Formally, this kind of stiffness matrix form is the same as in the case of isotropic plates, which is the consequence of geometrical or material or both geometric and material nonlinear treatment.

\section{SOFTWARE PACKAGE FOR THE ANALYSIS OF LAMINATED STRUCTURES}

5. PROGRAMSKI PAKET ZA ANALIZU LAMELIRANIH STRUKTURA

Stress and strain analysis of chair structures was conducted by application of software package KOMIPS for computer modeling and computation of structures, developed by Maneski (1998). This software system is based on the finite element method. It possesses a wide library of elements starting from one-dimensional to general three-dimensional elements that enable modeling of geometry and physical discretization of very complex structures.

For this paper, finite laminate element is of particular importance, since it represents the basis of all our numerical analyses. Finding of stiffness matrix of finite laminate element requires the integration per its volume (23). As mentioned above, the volume integration problem could be translated to the integration per surface of finite element by introduction of the socalled reduced stiffness (26) and (28), which makes stiffness matrix procedure formulation more efficient and identical to the classical plate theory. For this reason, subroutine REDKRUT for KOMIPS, that calculates reduced stiffness of the laminate, was applied.

\section{CONCLUSIONS AND RECOMMENDATIONS 6. ZAKLJUČCI I PREPORUKE}

On the basis of the above presented teorethical considerations, here are several conclusions and guidelines that were applied in further research (Nestorović, 2010).

1. For the determination of material constants as rheological material model for the conditions of planar stress, three separate uni-axial tension tests were conducted, for complex and uniform composition of laminate. In the tests, four independent elastic orthotropic constants of the modulus of electricity $E_{x}, E_{y}$, Poisson ration $v_{x y}$ and shear modulus $\mathrm{G}_{\mathrm{xy}}$ were determined. In these tests, Poisson coefficient $v_{y x}$ was also determined, but in the case when $v_{x y}$ is known, it does not represent independent elastic constant. Also, bending tests were conducted, the results of which were elasticity bending modules $\mathrm{E}_{\mathrm{fx}}, \mathrm{E}_{\mathrm{fx}}$ and stresses $\sigma_{x}, \sigma_{y}$.

2. Laminates with uniform composition of veneer sheets and complex composition of veneer sheets represent two composites, and in terms of rheology, two different material models. However, they are not independent, because material constants of complex composition could be unambiguously determined from the material constants of uniform composite, as shown by experimental results (Nestorovic, 2010).

3 . In section 4 the composite plate/shell finite element was formulated. Such finite element is applicable to the problems of membrane stress and bending of composite structures. Volume integration of stiffness matrix was translated in the integration per mid-plane of the plate by introducing of the so-called reduced stiffness of the composite both for membrane stress and bending. Kirchhoff-Love hypothesis of the flat sections of the plate after deformation, implies a linear change of componential deformation through the laminate thickness. Since the mechanical properties of layers are generally disparate, linear change of deformations leads to abrupt changes of componential stresses across the thickness of the composite. This is shown above in Figure 5 for the case of laminate composed of eight 1.5 -mm-thick layers.

Having in mind that the cross section of the plate represents the section defined by the unit width and plate thickness, it is clear that the composite section forces are resultants of the componental stresses, i.e. their integrals across the laminate thickness. Provided that the integrals across the thickness are the same at each abrupt change of the stress and fictitious linear change, reduced membrane and reduced bending stiffness of the composite were defined.

4. Theoretical, experimental and numerical researches, and introduction of the reduced stiffness of complex laminate in the finite elements, together with the experiments on chairs (Nestorović, 2010) that were done in order to determine the stiffness of such systems by measurement of real displacements on the selected

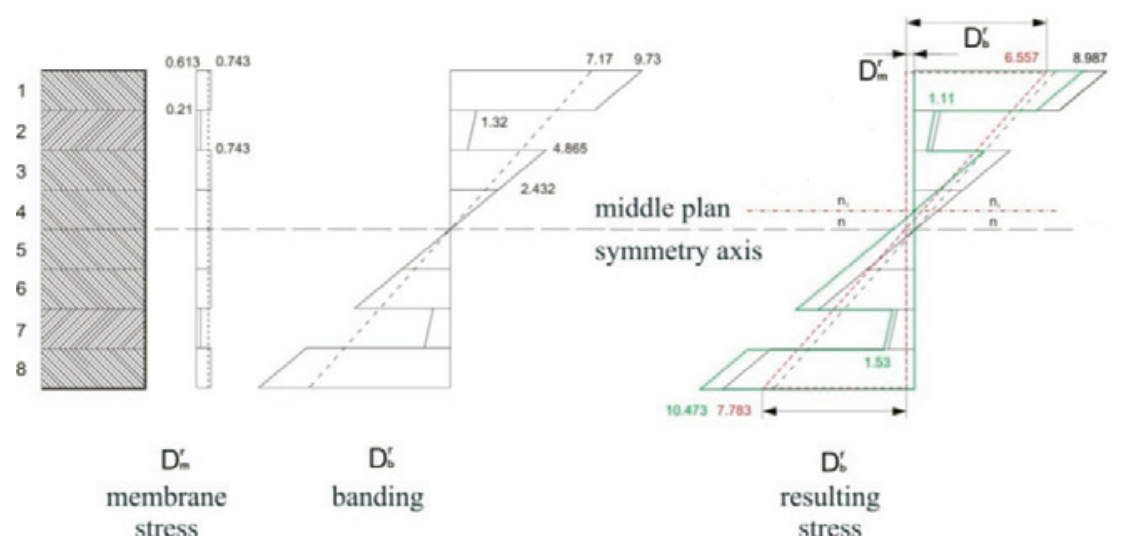

Figure 5 Reduced stiffness

Slika 5. Reducirane krutosti 
models, confirmed numerical calculations, enabling design, redesign, construction and dimensioning of not only chairs but of any beam or surface system based on the laminate, by varying material type, combination of diverse materials, layer thickness and fiber orientation.

5. Using the acquired knowledge with the aim of determining material constants of orthotropic composites, the following experimental tests were proposed:

5.1 Production of specimens of massive structure (all fibers oriented in the same direction) in the form of the cube (Figure 6). By uni-axial tensioning in x-direction, it was possible to determine elasticity modulus $E_{x}$ and Poisson coefficient $v_{x y}, v_{x z}$. Tensioning in the y-direction will result in modulus of elasticity $\mathrm{E}_{\mathrm{y}}$ and coefficients $v_{y x}, v_{y z}$. The same test in the z-direction will give $\mathrm{E}_{\mathrm{z}}$ and $v_{z x}, v_{z y}$. From here it is clear that, in the case of orthotropic composite, only six out of nine constants are mutually independent $E_{x}, E_{y}, E_{z}, v_{x y}, v_{x z}, v_{y z}$.

5.2 For the determination of three independent material constants that contain shear modulus in $x y$-, $x z-$, and $y z$ - planes, the following experiment was proposed: to make a specimen of the massive structure in the form of the cube with the fibers oriented in the same direction as presented in Figure 6. vectors

Local plan of the lamina is defined by the unit

$$
\vec{i}_{1}=\frac{1}{\sqrt{2}}\left[\begin{array}{lll}
0 & 1 & 1
\end{array}\right] \quad \vec{i}_{2}=\frac{1}{\sqrt{3}}\left[\begin{array}{lll}
-1 & 1 & -1
\end{array}\right]
$$

which implies that its normal equals

$$
\vec{i}_{3}=\vec{i}_{1} \times \vec{i}_{2}=\frac{1}{\sqrt{6}}\left[\begin{array}{lll}
-2 & -1 & 1
\end{array}\right]
$$

In this case, the relation between local $x, y$ and $z$ and global $X, Y$ and $Z$ coordinates is given by the relation

$$
\left[\begin{array}{l}
x \\
y \\
z
\end{array}\right]=\left[\begin{array}{ccc}
0 & \frac{\sqrt{2}}{2} & \frac{\sqrt{2}}{2} \\
-\frac{\sqrt{3}}{3} & \frac{\sqrt{3}}{3} & -\frac{\sqrt{3}}{3} \\
-\frac{\sqrt{6}}{3} & -\frac{\sqrt{6}}{6} & \frac{\sqrt{6}}{6}
\end{array}\right]\left[\begin{array}{l}
X \\
Y \\
Z
\end{array}\right]
$$

Using the property of stress and strain tensor, components of shear stresses and shear deformations in the local xy-, xz- and yz-planes, due to the tension in all three global directions, are determined by expressions

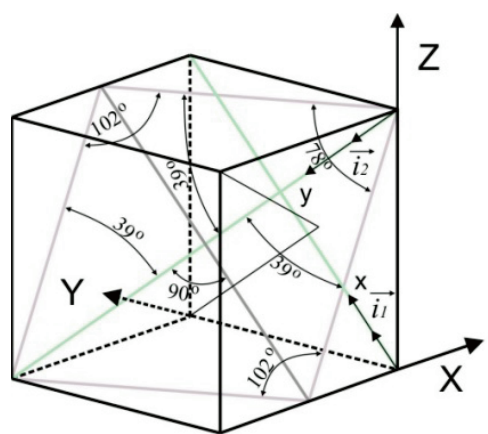

Figure 6 Test cube for determination of shear elasticity constants

Slika 6. Probna kocka za određivanje smičnih konstanti elastičnosti

$$
\begin{aligned}
& \tau_{x y}=\frac{\sqrt{6}}{6}\left(\sigma_{Y}-\sigma_{Z}\right) \quad \tau_{x z}=\frac{\sqrt{3}}{6}\left(\sigma_{Z}-\sigma_{Y}\right) \\
& \tau_{y z}=\frac{\sqrt{2}}{3}\left(\sigma_{X}-\frac{1}{2} \sigma_{Y}-\sigma_{Z}\right) \quad \gamma_{x y}=\frac{\sqrt{6}}{3}\left(\varepsilon_{Y}-\varepsilon_{Z}+\frac{\sqrt{3}}{2} \varepsilon_{X}\right) \\
& \gamma_{x z}=\frac{\sqrt{3}}{3}\left(\varepsilon_{Z}-\varepsilon_{Y}\right) \quad \gamma_{y z}=-\frac{\sqrt{2}}{3}\left(\varepsilon_{Y}+\varepsilon_{Z}\right)
\end{aligned}
$$

In accordance with the expressions (36), assuming the uni-axial tension in $Y$-direction, i.e.

$$
\sigma_{Y} \neq 0 \quad \sigma_{X}=\sigma_{Z}=0
$$

the equation for the shear stress is

$$
\tau_{x y}=\frac{\sqrt{6}}{6} \sigma_{Y} \quad \tau_{x z}=-\frac{\sqrt{3}}{6} \sigma_{Y} \quad \tau_{y z}=\frac{\sqrt{2}}{6} \sigma_{Y}
$$

where the resulting shear moduli $G_{x y}, G_{x z}$ and $G_{y z}$ are in the form of

$$
\begin{aligned}
G_{x y} & =\frac{\tau_{x y}}{\gamma_{x y}}=\frac{\sigma_{Y}}{2\left(\varepsilon_{Y}-\varepsilon_{Z}+\frac{\sqrt{3}}{2} \varepsilon_{X}\right)} G_{x z}=\frac{\tau_{x z}}{\gamma_{x z}}=\frac{\sigma_{Y}}{2\left(\varepsilon_{Y}-\varepsilon_{Z}\right)} \\
G_{y z} & =\frac{\tau_{y z}}{\gamma_{y z}}=\frac{\sigma_{Y}}{2\left(\varepsilon_{Y}+\varepsilon_{Z}\right)}
\end{aligned}
$$

In analogue test that assumes tension in the global Z-direction, i.e.

$$
\sigma_{Z} \neq 0 \quad \sigma_{X}=\sigma_{Y}=0
$$

components of the shear stress are

$$
\tau_{x y}=-\frac{\sqrt{6}}{6} \sigma_{Z} \quad \tau_{x z}=\frac{\sqrt{3}}{6} \sigma_{Z} \quad \tau_{y z}=-\frac{\sqrt{2}}{3} \sigma_{Z}
$$

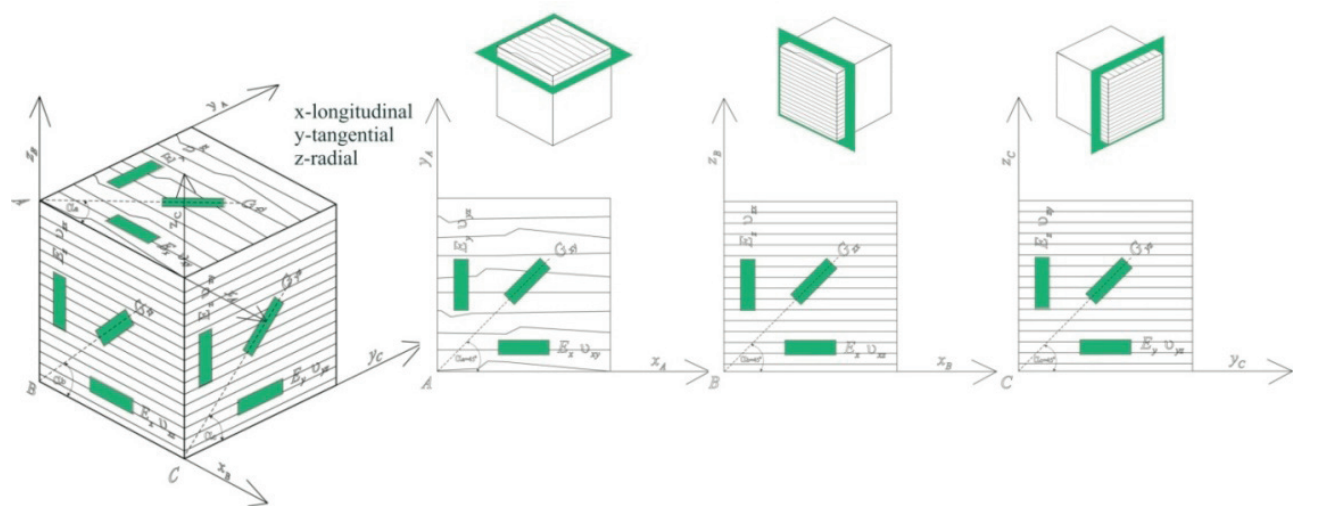

Figure 7 Test cube for determination of shear elasticity constants - scheme of cutting test specimens Slika 7. Probna kocka za određivanje smičnih konstanti elastičnosti - shema izrezivanja testnih uzoraka 

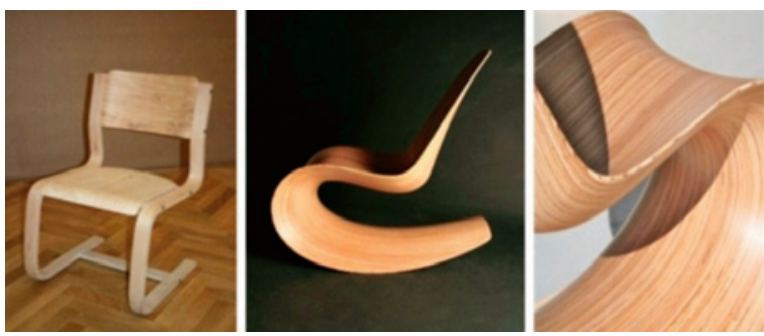

Figure 8 Cantilever chair from the doctoral thesis of B. Nestorović (left);free-form chair "Savannah Rocker III" made of uniform laminate by designer J. Yates, from http:// www.fabulise.com/xodechair.com/ (middle and left) Slika 8. Konzolni stolac iz doktorskog rada B. Nestorović (lijevo); slobodno oblikovani stolac Savannah Rocker III dizajnera J. Yatesa (preuzeto s http://www.fabulise.com/ xodechair.com/) (sredina i desno)

while shear moduli are expressed as

$$
\begin{aligned}
G_{x y} & =\frac{\sigma_{Z}}{2\left(\varepsilon_{Z}-\varepsilon_{Y}-\frac{\sqrt{3}}{2} \varepsilon_{X}\right)} G_{x z}=\frac{\sigma_{Y}}{2\left(\varepsilon_{Z}-\varepsilon_{Y}\right)} \\
G_{y z} & =\frac{\sigma_{Z}}{\left(\varepsilon_{Y}+\varepsilon_{Z}\right)}
\end{aligned}
$$

Since expressions (37) and (39) give the same values, it is clear that only one test is necessary, while the other test can be used as control.

6. Based on the results obtained in experiments 5.1 and 5.2, material flexibility matrix $\mathrm{S}$ can be defined as well as constitutive matrix $\mathrm{C}$, i.e.

$$
S=\left[\begin{array}{cccccc}
\frac{1}{E_{x}} & -\frac{v_{y x}}{E_{y}} & -\frac{v_{z x}}{E_{z}} & 0 & 0 & 0 \\
-\frac{v_{x y}}{E_{x}} & \frac{1}{E_{y}} & -\frac{v_{z y}}{E_{z}} & 0 & 0 & 0 \\
-\frac{v_{x z}}{E_{x}} & -\frac{v_{y z}}{E_{y}} & \frac{1}{E_{z}} & 0 & 0 & 0 \\
0 & 0 & 0 & \frac{1}{G_{y z}} & 0 & 0 \\
0 & 0 & 0 & 0 & \frac{1}{G_{z x}} & 0 \\
0 & 0 & 0 & 0 & 0 & \frac{1}{G_{x y}}
\end{array}\right] \Rightarrow C=S^{-1}
$$

and dependencies between components of stress and strain tensors can be established in the form of

$$
\sigma=C \varepsilon
$$

where $\sigma$ and $\varepsilon$ represent the above defined vectors of stress and strain.

Relation (41) enables stress and strain analysis of the orthotropic and anisotropic composite structures that have a 3D character. In the static terms, they represent thick plates and shells, in which shear deformation in planes $(x-z, y-z)$ perpendicular to the middle plane of plate/shell $(x-y)$ could not be neglected.

Further to the above, Figure 8 presents models of chairs that illustrate the possibilities of application of developed apparatuses in the process of design and redesign, regardless of shape, type of material, thickness of layers, or fiber orientation.

\section{Acknowledgment - Zahvala}

Research is supported by the Ministry of Education, Science and Technological Development of Republic Serbia, Project No. TR36008.

\section{REFERENCES}

7. LITERATURA

1. Bathe, K. J., 1996: Finite Element Procedures. USA, Prentice - Hall, Inc.

2. Hughes, T. J. R., 1987: The Finite Element Method: Linear Staticand Dynamic Finite Element Analysis. New Jersey, Prentice-Hall.

3. Jones, R. M., 1975: Mechanics of Composite Materials. Washington, D. C., Script Book Co., pp. 31-54, 147-171.

4. Maneski, T., 1998: Computer modeling and calculation of structures. Belgrade, University of Belgrade, Faculty of Mechanical Engineering.

5. Nestorović, B.; Grbac, I., 2011: Validation numerical modelling with 3D optical measurement deformations. Ambienta, Proceedings of the 22th International Scientific Conference - Wood is Good, Faculty of Forestry, Zagreb University, pp. 141-148.

6. Nestorović, B.; Grbac, I.; Nestorović, P., 2012: Experimental Determination of Elastic Constants of Veener Composites. Ambienta, Proceedings of the 23th International Scientific Conference - Wood is Good, Faculty of Forestry, Zagreb University, pp. 127-138.

7. Nestorović, B., 2010: Research and Analysis of the Strength of Wood-Laminate Seating Furniture. Doctoral thesis. Belgrade, University of Belgrade Faculty of Forestry, pp. 80-100.

8. Nestorović, B.; Skakić, D.; Grbac, I., 2011: Determining the Characteristics of Composite Structure Laminae by Optical 3D Measurements of Deformation with Numerical Analysis. Drvna industrija, 62 (3): 193-200 http:// dx.doi.org/10.5552/drind.2011.1103.

9. Nestorović, B.; Grbac, I.; Nestorović, P., 2013: Numerical Analysis of Laminated Wood Structures - Chairs by Application of FEA. Ambienta, Proceedings of the24th International Scientific Conference - Wood is Good, Faculty of Forestry, Zagreb University, pp. 101-109.

10. Vlaović, Z.; Grbac, I.; Domljan, D.; Bublić, A., 2010: Office Work Chairs - Research of Deformations and Comfort Index. Drvna industrija, 61(3): 159-168.

\section{Corresponding address:}

Assist. Prof. BISERKA NESTOROVIĆ, Ph.D.

Department for Final Wood Processing

University of Belgrade, Faculty of Forestry

KnezaVišeslava 1

11030 Belgrade, Serbia

e-mail: biserka.nestorovic@sfk.rs 